\title{
Weights of evidence method for landslide susceptibility mapping in Tangier, Morocco
}

\author{
Mahfoud BOUSTA ${ }^{1}$, Lahsen AIT BRAHIM ${ }^{1}$ \\ ${ }^{1}$ Université Mohammed V, Faculté Sciences, Département Sciences de la Terre, Unité de recherche GEORISK: Risques \\ Géologiques, Télédétection et développement durable. Avenue Ibn Battouta Rabat - Agdal, Boîte Postale 1014, Rabat, \\ Maroc
}

\begin{abstract}
Tangier region is known by a high density of mass movements which cause several human and economic losses. The goal of this paper is to assess the landslide susceptibility of Tangier using the Weight of Evidence method (WofE). The method is founded on the principle that an event (landslide) is more likely to occur based on the relationship between the presence or absence of a predictive variable (predisposing factors) and the occurrence of this event. The inventory, description and analysis of mass movements were prepared. Then the main factors governing their occurrence (lithology, fault, slope, elevation, exposure, drainage and land use) were mapped before applying WofE. Finally, the ROC curves were established and the areas under curves (AUC) were calculated to evaluate the degree of fit of the model and to choose the best landslide susceptibility zonation. The prediction accuracy was found to be $70 \%$. Obtained susceptibility map shows that $60 \%$ of inventoried landslides are in the high to very high susceptibility zones, which is very satisfactory for the validation of the adopted model and the obtained results. These zones are mainly located in the N-E and E part of the Tangier region in the soft and fragile facies of the marls and clays of the Tangier unit, where landuse is characterized by dominance of arable and agricultural land (lack of forest cover). From a purely spatial point of view, the localization of these two classes of susceptibility is completely corresponding to the ground truth data, that is to say that all the environmental and anthropogenic conditions are in place for making this area prone to landslide hazards. The obtained map is a decision-making tool for presenting, comparing and discussing development and urban scenarios in Tangier. These results fall within the context of sustainable development and will help to mitigate the socio-economic impacts usually observed when landslides are triggered.
\end{abstract}

Key words: Weights of evidence, landslides, susceptibility map, spatial analysis, predisposing factors, probabilistic modeling, GIS, urban planning, Rif, Northern Morocco.

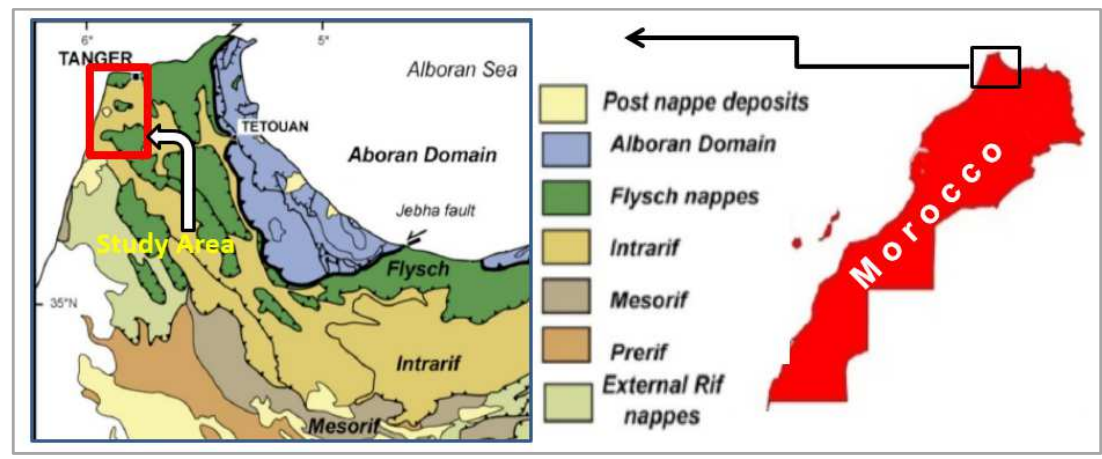

Fig. 1. Study area. 


\section{Introduction}

Landslides belong to natural hazards facing Morocco, especially in the Rif regions [1-7]. It brought about significant environmental and socio-economical losses consequences in recent decades: Road cuts (34\%); Subsidence of roads (18\%); Destruction of habitat (18\%); Collapse of railways (12\%); destruction of a large number of hydraulic infrastructures .Every year about $50 \%$ (or more) of the total budget allocated to the DPTP (Provincial Commands of Public Works) of the Rif is destined for reinforcement, retaining and repair works of roads because of the occurrence of a large number of mass movements that most often damage the same areas already studied and treated, and it is due to the fact that landslides are not taken in their overall geodynamic context of the watershed, the use of non-adapted methods based on very subjective opinions, the inappropriate choice of scale and especially the pressure imposed by the urgency of reopening the road to traffic to supply the main cities and towns of the Rif. In view of the region's economic development with large land-use planning projects; It is of great interest to develop a landslide susceptibility map of a predictive nature to define the most exposed areas to mass movements. Thus, the main objective of this study is to identify the predictive variables for the assessment and development of this map using the weight of evidence theory [8]. Like other methods [9-15], it is based on the principle that "the past and the present landslide locations are the key to the future" [16]

\section{Study area}

The Tangier region, located at the NW end of the Moroccan Atlantic coast, is bounded on the north by the Strait of Gibraltar, on the south by Wadi Rharifa, on the west by the Atlantic Ocean and on the east by the plain of Fahs. From a demographic point of view, Tangier is the third largest city in Morocco with 974,000 inhabitants, with an average density of 451 inhabitants $/ \mathrm{km}^{2}$. The climate ranges between the humid Mediterranean and subhumid in warm winter. The average summer temperature is $28,6^{\circ}$. The winter is characterized by its softness. The average temperature of the coldest month is $8,5^{\circ}$ and the average annual rainfall is $800 \mathrm{~mm}$. Violent winds reach $29 \%$ with a speed of between 25 and 50 $\mathrm{km} / \mathrm{h}$ [17]. In winter, winds are humid from the west, linked to the Azores High which is centered on the Canary Islands, but when the anticyclone is displaced on the Iberian side, the often violent winds are NE direction. In summer it is a warm, dry east wind (Chergui) which blows in gusts (speed over 50kms / h) 2 to 3 days in a row, several times a month.Tangier is located in the external domain of the Rif's chain, where the Rif is the western end of the Maghrebian Alpine chain outcropping along the Mediterranean coast of North Africa from Calabria to the Gibraltar Arc [18-19]. The elevation of the region is characterized by massifs of low mountains bordered by hills with a powerful sandstone mass of the Numidian nappe which generally occupies a high structural position. It forms well marked ridges, armed by the numerous sandstone benches slicing on hills of a Cretaceous substratum. The extreme north of the littoral zone is characterized by a rocky coast. The plain of Fahs is open towards the south with sandy beaches which are sometimes associated with dunes. Such a morphology is the result of the combination of highly contrasted lithology, climatic system, active tectonic regime, and the erosive dynamics giving rise to several mass movements.

\section{Landslides and predisposing factors}

Using remote sensing imagery, existing maps and field data, we have inventoried landslides, prepared and mapped predisposing factors. Then, we have converted all maps into 30m pixel size's raster format with "Nord Maroc: Lambert Conformal Conic" geographic projection using Arcgis10.Thus, we have mapped 118 landslides that were all checked on the ground. It is difficult to differentiate the typology of mass movements due to the complexity of the land nature and morphology [1]. According to the most dominant morphological traits [20], we recognized four types: Rockfalls, Slides, Mud flows and complex landslides. The typology varies as much as possible the above categories movements combines.According to literature, lithology, faults, elevation, gradient of slope, slope exposure, Drainage network and land use are the most commonly used factors to assess landslide susceptibility in the region. Thus, we used all of them to lead this study. The lithological map (Figure2.b) contains five classes sandstone (35\%), marls and argillites (21\%), marls sandstone $(18 \%)$, silts $(18 \%)$ and sands $(8 \%)$. The occurrence and spatial distribution of inventoried landslides show that a large number of complex slides and mudflows develop on outcrops of argillite marls and sandstones. The faults shapefile was made by digitizing the $1 / 50,000$ th geological maps combined with image processing and field studies. This shapefile was later converted to fault density map by using Kernel method and classified in 5 classes. From ASTER digital elevation model (GDEM), we have derived elevation, slope, and exposure factors. In the elevation map we recognize different geomorphological zones: Low altitudes between 0 and 100m of Fahs, Charf Laquab, Marhar, El Hachef and Asilah plains. Medium altitudes between 100 and $300 \mathrm{~m}$ corresponding to Dar Zhirou and Haouta Ben Mediar slope, and the high altitudes between 300 and $700 \mathrm{~m}$ representing the ridge lines of Randa $(326 \mathrm{~m})$, Haouch Ben Kreaa $(643 \mathrm{~m})$ and Dar Chaoui $(=477 \mathrm{~m})$. The slope map (Figure2.e) was classified into five classes. We 
observed that the most favourable slopes to instability are those whose inclination is moderate. Based on the knowledge of our study area, we have classified the map into five classes: $\mathrm{N}$ and flat; NE-E-SE, SW-W; NW. Landuse mapping was carried out by interpreting satellite images and aerial photographs' supervised multi-spectral classification coupled with vegetation cover data o and especially of the forest species made available to us by the HCEFLCD (High Commission for Water and Forests and the Fight against Desertification). This work has been supplemented and updated by collected and/or verified data by our observations at a number of points accessible on the ground (2015-2016). The final document (Figure2.g) has undergone several mergers and adjustments of homogeneous objects in order to make its reading and use more simplified. It then contains the following classes: Buildings and bare land; water and swamps; forests; arable and agricultural land; natural vegetation. The density map of the hydrographical network (Figure2.g) takes into account both the cumulative length of the drainage network and the presence of the hydrographical nodes. The map realized contains 5 classes of density namely: very low; low; moderate; high and very high.

\section{Modelling Methodology}

Weight of Evidence (WofE) is a log-linear version of the Bayes general theorem, and was originally applied in medicine to diagnose certain diseases. It's a bivariate analysis consists of a relation between the predictive variables of a phenomenon (PV) and the occurrence of this phenomenon (dependent variable, DV: in this case the landslides). The theory is based on three hypotheses [14]: (a) potential landslides will occur under the same conditions as in the past; (b) the predisposing factors are priori known and introduced into the analysis; (c) all landslides are inventoried on the study area. It uses Bayesian statistics to calculate the degree of spatial association between a set of variables DV and predictive factors $\mathrm{PV}$, assigns weights to them, and then uses a mathematical summation technique to summarize the weighted factor maps in one posterior probability map.The a priori probability is the probability that a unit of land (calculation grid) has the dependent variable (VD), calculated from its density on the study area. The posterior probability is estimated after the calculation of the priori probabilities according to the density of DV for each predictive variable $\mathrm{PV}$, in our case each predisposing factor. This association between the DV and the PV will thus make it possible to calculate a positive weight $\mathrm{W}+$ and a negative weight $\mathrm{W}$ - for each predictive variable, corresponding respectively to a greater or a lower probability of occurrence of DV.
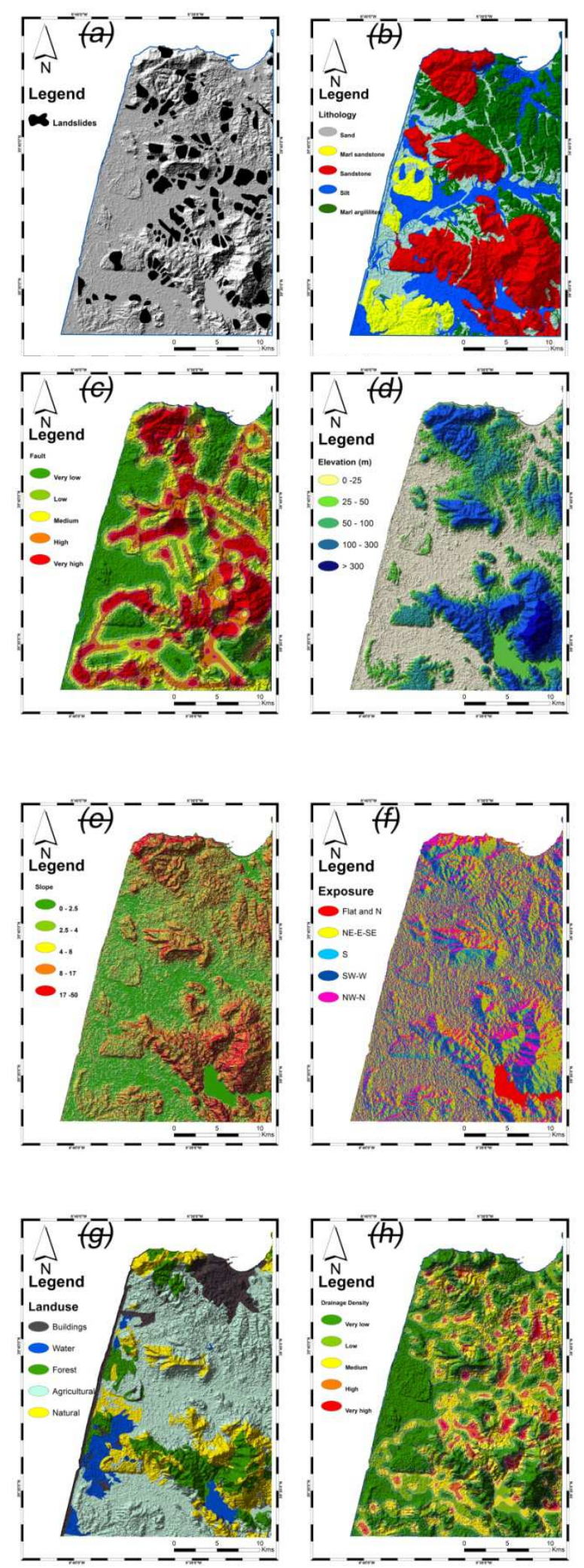

Fig. 2. Landslides and factors maps

$\mathrm{W}^{+}=\ln \frac{\mathrm{P}\{\mathrm{PV} / \mathrm{DV}\}}{\mathrm{P}\{\mathrm{PV} / \overline{\mathrm{DV}}\}}$

$\mathrm{W}^{-}=\ln \frac{\mathrm{P}\{\overline{\mathrm{PV}} / \mathrm{DV}\}}{\mathrm{P}\{\overline{\mathrm{PV}} / \overline{\mathrm{DV}}\}}$

Landslide susceptibility and treatments were performed using the ArcGIS' ArcSDM® extension [21-23] Data collection and preparation is done using a multisource approach (ground truth, thematic maps, spatial 
techniques, etc.). However, the different stages of this approach can be summarized in these points: Preparation of data, WofE application, model validation and landslide susceptibility map generation.

\section{Results and discussion}

\subsection{Predictive factors' weights}

Analyzing $\mathrm{W}+, \mathrm{W}$ - and final weight $(\mathrm{W})$ values assigned to each of the classes of the predictive variables, has allowed us to evaluate and interpret the respective roles of each predisposing factors in the spatial occurrence of landslides. We noted that land use, elevation and fracturing play a major role and that the density of the drainage and the exposure are relatively less influential whereas the slope and the lithology occupy an intermediate place in the triggering of the landslides. Indeed, the value of the maximum weight contrast between the five classes of the drainage density variable is only 0.4 , while it is -2.1 for land use and -1.3 for elevation. Slope and lithology variables have a maximum contrast value of 0.92 and -0.95 respectively. Among all the predictive variables, land use is the one that has the greatest impact on the model, notably due to the low susceptibility of forests in landslides' triggering, followed by elevation because of the low susceptibility of high altitudes. Conversely, lithology is characterized by the high susceptibility of marl-argilites and fracturing characterized by the high susceptibility of zones with average fault concentration.

\subsection{Conditional Independence assessment}

WofE modeling assumes conditional independence (CI) between the layers of evidence (predictive factors). If all themes of evidence are conditionally independent, then the (predicted) calculated number of landslides will be equal to the observed [23]. In practice, when working with geological data, conditional independence $(\mathrm{CI})$ is always violated [22-23] The question is that the expert must assess the degree of the violation (Bonham-Carter, 1994). The ArcSDM® tool provide 3 tests for conditional independence between layers:

1. Conditional independence ratio (CI ratio): The CI ratio is equal to $\mathrm{n} / \mathrm{T}$, where values below 1.00 may indicate conditional dependence among two or more sets of data. Bonham-Carter [22] suggests that values $<0.85$ may indicate a problem..

2. The overall CI test was based on an informal " 10 - $15 \%$ rule" proposed by Bonham-Carter [22] which suggests that if the predicted number of deposits $(\mathrm{T})$ is more than 10 - 15\% greater than the observed number of deposits (n), then there may be an issue with the extant of violation of conditional independence. $\mathrm{T}$ is calculated as the sum of the posterior probabilities weighted according to unit cell area [22], while $\mathrm{n}$ is simply the number of training points.

3. Agterberg-Cheng (AC) test" [23] tests whether "T-n" is "significantly greater than zero". This is a onetailed test of the null hypothesis that $\mathrm{T}-\mathrm{n}=0$. The test statistic is $(\mathrm{T}-\mathrm{n}) / \sigma \mathrm{T}$.

\begin{tabular}{|c|c|c|c|c|c|c|}
\hline Factor & Class & $\begin{array}{c}\text { Area } \\
(\mathrm{km} 2)\end{array}$ & $\mathrm{W}+$ & W- & $\mathrm{C}$ & W \\
\hline \multirow{5}{*}{ Litho } & Silt & 120.07 & 0 & 0 & 0 & -0.26 \\
\hline & Sandstone & 234.35 & 0.105 & -0.06 & 0.165 & -0.26 \\
\hline & $\begin{array}{c}\text { Marl- } \\
\text { sandstone }\end{array}$ & 57.67 & -0.9 & 0.057 & -0.96 & -0.26 \\
\hline & $\begin{array}{c}\text { Marl- } \\
\text { argilites }\end{array}$ & 142.45 & 0.669 & -0.26 & 0.932 & 0.669 \\
\hline & Sand & 121.22 & 0.119 & -0.03 & 0.147 & -0.26 \\
\hline \multirow{5}{*}{ Fault } & Very low & 155.91 & -0.8 & 0.162 & -0.96 & -0.8 \\
\hline & Low & 95.77 & 0.271 & -0.05 & 0.323 & 0.108 \\
\hline & Midium & 158.87 & 0.743 & -0.36 & 1.105 & 0.743 \\
\hline & High & 148.45 & -0.01 & 0.003 & -0.01 & 0.108 \\
\hline & Very high & 114.84 & -1.61 & 0.164 & -1.78 & -1.61 \\
\hline \multirow{5}{*}{ Slope } & $0-2.5$ & 202.7 & -0.11 & 0.043 & -0.15 & -0.12 \\
\hline & $2.5-4$ & 60.13 & 0.809 & -0.12 & 0.925 & 0.809 \\
\hline & $4-8$ & 149.65 & -0.11 & 0.031 & -0.14 & -0.12 \\
\hline & $8-17$ & 217.62 & -0.05 & 0.022 & -0.07 & -0.12 \\
\hline & $17-50$ & 43.75 & -0.62 & 0.033 & -0.65 & -0.12 \\
\hline \multirow{5}{*}{ Expo } & $\mathrm{P}-\mathrm{N}$ & 62.93 & -0.27 & 0.025 & -0.29 & -0 \\
\hline & NE-E-SE & 235.93 & 0.288 & -0.19 & 0.477 & -0 \\
\hline & $\mathrm{S}$ & 84.11 & -0.15 & 0.019 & -0.17 & -0 \\
\hline & SW W & 172.92 & -0.18 & 0.055 & -0.23 & -0 \\
\hline & NW & 117.96 & -0.2 & 0.038 & -0.24 & -0 \\
\hline \multirow{5}{*}{ Landuse } & $\begin{array}{l}\text { Buildings } \\
\& \text { bareland }\end{array}$ & 53.91 & -0.41 & 0.03 & -0.44 & -0.29 \\
\hline & $\begin{array}{l}\text { Water \& } \\
\text { swamps }\end{array}$ & 39.07 & 0 & 0 & 0 & -0.29 \\
\hline & Forsts & 83.78 & -1.99 & 0.125 & -2.12 & -1.99 \\
\hline & $\begin{array}{c}\text { arable \& } \\
\text { agricultural } \\
\text { land }\end{array}$ & 382.59 & 0.302 & -0.57 & 0.87 & 0.302 \\
\hline & $\begin{array}{c}\text { Natural } \\
\text { vegetaion }\end{array}$ & 115.5 & 0.066 & -0.01 & 0.08 & -0.29 \\
\hline \multirow{5}{*}{ Elevation } & $0-25$ & 285.55 & 0.077 & -0.06 & 0.136 & 0.137 \\
\hline & $25-50$ & 133.62 & 0.353 & -0.11 & 0.458 & 0.137 \\
\hline & $50-100$ & 127.43 & 0.157 & -0.04 & 0.196 & 0.137 \\
\hline & $100-300$ & 111.8 & -1.17 & 0.137 & -1.31 & -1.17 \\
\hline & $>300$ & 15.45 & 0 & 0 & 0 & 0.137 \\
\hline \multirow{5}{*}{ Drainage } & Very low & 234.04 & -0.5 & 0.198 & 0.337 & -0.5 \\
\hline & Low & 223.7 & -0.08 & 0.037 & 0.304 & 0.099 \\
\hline & Medium & 162.74 & 0.336 & -0.13 & 0.303 & 0.099 \\
\hline & High & 48.01 & 0.811 & -0.09 & 0.416 & 0.811 \\
\hline & Very high & 5.35 & 0 & 0 & 0 & 0.099 \\
\hline
\end{tabular}

Table 1. Weights and contrast(c) for each factor 
Probability values greater than $95 \%$ or $99 \%$ indicate that the hypothesis of CI should be rejected, but any value greater than $50 \%$ indicates that some conditional dependence occurs [23].

The different tests showed that the model respects the hypothesis of conditional independence, since there is no major difference $(\mathrm{T}-\mathrm{n}=3.3)$ between the expected landslides (T) and those observed (n). We note that the value of the CI ratio $=0.94$ is greater than the threshold value of 0.85 . The $50.1 \%$ value of the Agterberg-Cheng test is almost perfect. Thus, the hypothesis of conditional independence is attested to be valid for the model, which is also confirmed by the third Overall test $\mathrm{CI}=99.8 \%$.

\subsection{Validation}

To check the performance of the model, we analyzed the posterior probability map, using the SRC and RPC efficiency curves which are the most important means to evaluate and validate the probability map. We used $50 \%$ of all landslides inventoried to create the SRC (success-rate curve) that test how well the posterior probability fits the used. We also used the rest of landslides $(50 \%)$ that were not introduced into the model to generate the PRC (Prediction-rate curve) which is a blind test that evaluates how well our model predicts unknown landslides. It is therefore the true test of validation of our model.

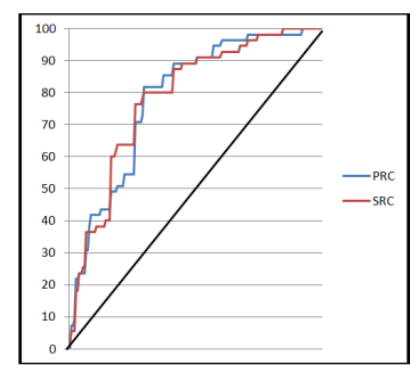

Fig. 3. Success and Prediction rate curves.

Figure 3 shows the prediction and success rate curves of the landslide susceptibility map. The shape of the two curves is very similar, which confirms that $50 \%$ of the landslides points are sufficient to obtain good results. The two curves show that the model has a success efficiency of $70.0 \%$ for known slides distribution and an unknown ones' prediction efficiency of $70.7 \%$.

After validation of the probability map, it was classified into five classes using the reclassification of arcgis' Naural breaks (Jenks).The statistical result of this superposition showed that $60 \%$ of inventoried landslides are in the zone of high to very high susceptibility, which is very satisfactory for the validation of the resulting map. High susceptibility zones are located mainly in the NE and $\mathrm{E}$ part of the Tangier region, first between the southern slope of Jbel Ronda (spartel) and the north slope of Jbel Zhirou and then north of the slopes of the hills of Haouta Ben Mediar and Haouch Ben Kreaa. They are superimposed on the soft and fragile facies of the marls and clays of the Tangier unit, whose land use is dominated by arable and agricultural land and by bare ground (absence of forest cover), where slope is between $7^{\circ}$ and $17^{\circ}$ and the fracturing and the drainage densities are high to very high (with zones of tectonic nodes).From a purely spatial point of view, the localization of its two susceptibility classes is in a complete agreement with the data of the ground truth. That is to say that all the environmental and anthropogenic conditions are met and favourable for this zone to be predisposed to the triggering of the landslides. The zones of low to very low susceptibility present about $20 \%$ of instabilities. It covers the areas of the coastal plains between Asilah to the south and the cave of Hercules to the north. The flatlands at the level of the valleys of wadis of Tahadart and El Hachef which can be explained by the very soft slopes generally less than $7^{\circ}$. These slopes, although unfavourable to the genesis of gravity movements, are characterized by severe gullying (badlands) and runoff in marly and clayey formations, especially during periods of occasional floods. Areas of low susceptibility are the reliefs where the most resistant lands of the Tangier region (Numidian sandstones) are partly stabilized by the development of a high density forest.

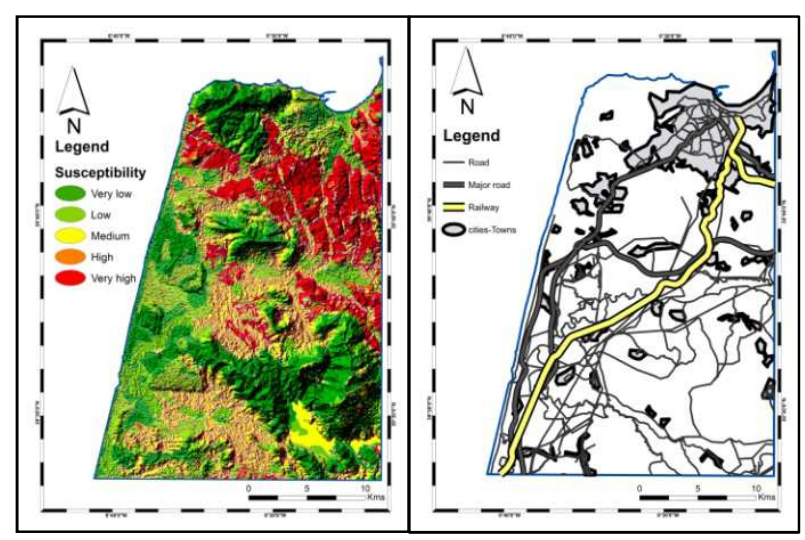

Fig. 4. Landslide susceptibility map(left) and buildings and transportation map(right)

\section{Conclusions}

In this paper, Weight of Evidence method was applied for landslide susceptibility mapping in Tangier. After classifying the posterior probability, the efficiency of how well the model distributes used landslides has been calculated. It was found to be equal to $71 \%$. Then, the obtained susceptibility map has been furthermore validated by a cross-tabulation with the non-used landslide to evaluate the prediction accuracy of the model (70\%). Moreover, the resulting landslide susceptibility map shows that the high to very high susceptibility zones have the highest percentage $(60 \%)$ of all inventoried landslides in comparison with the other zones. Until 2000 the construction and buildings were focused in low susceptibility areas, but since 2004 the urban extension has began to occupy high susceptibility zones, which tends to increase vulnerability and therefore the risk of mass instability. Thus, the obtained landslide 
susceptibility map represents a clear view of the present instability and its possible future occurrences. It may helps widely in managing urbanism and construction in Tangier.

\section{References}

1. Milles-Lacroix A. Les glissements de terrains. Présentation d'une carte prévisionnelle des mouvements de masse dans le Rif (Maroc septentrional). Mines et Géologie, $\mathrm{n}^{\circ}$ 27. p. 45-55 (1968).

2. Ait Brahim L, Chotin P, Hinaj S, Abdelouafi A, El Adraoui A, Nakhcha C, Dhont D, Charroud M, Sossey Alaoui F, Amrhar M, Bouaza A, Tabyaoui H, Chaouni A. Paleostress evolution in the Moroccan African margin from Triassic to Present. Tectonophysics, Volume 357, Issues 1-4, Pages 187205 (2002).

3. El Khattabi J. and Carlier E. Tectonic and hydrodynamic control of landslides in the northern area of the Central Rif, Morocco. Engineering Geology p. 255-264 (2004).

4. El Kharim Y. Etude des mouvements de versants dans ta région de Tétouan (Rif occidental): lnvenentaire, analyse et cartographie. Thèse de Doctorat Es-Sciences, Université Abdelmalek Essaadi, Tétouan. Maroc, 250 p(2002).

5. Mansour M. Et Ait Brahim L. Utilisation de la télédétection pour l'analyse de la fracturation $d u$ domaine interne rifain (Maroc): relation avec la répartition des sources. Télédétection, Vol. 5, $\mathrm{n}^{\circ} 1-2-$ 3, p 95-103(2005).

6. Ait Brahim L., Sossey Alaoui F., Siteri H., Tahri M., Baghdada B., Prise en compte des glissements de terrain dans la quantification des pertes en sols dans le bassin versant Nakhla. Bulletin du Réseau d'Erosion, $n^{\circ}$ 21, p.50-64 (2002).

7. M.Mastere, B. Van Vliet Lanoë \& L. AïtBrahim L, "Land use mapping and its relation to mass wasting and gullying in NorthWestern Rif (Morocco)." Geomorpholog, relief, process, environment, 3, 335352, (2013).

8. Bonham-Carter G.F, Agterberg F.P, Wright D.F. Weights of evidence modeling: a new approach to mapping mineral potential. In: Agterberg, F.P., Bonham-Carter, G.F. (Eds.), Statistical Applications in the Earth Science: Geological Survey of Canada Paper, vol. 89-9, pp. 171-183 (1989).

9. Soeters R et Van Westen C.J. Slope instability recognition, analysis, and zonation. In: Turner, K.A., Schuster, R.L. (Eds.), Landslides: Investigation and Mitigation. Transport Research Board Special Report 247. , pp. 129-177(1996).

10. Guzzetti F, Carrara A, Cardinali M, Reichenbach P. Landslide hazardevaluation:areview of current techniques and their application in a multiscalestudy, central Italy. Geomorphology 31, 181216(1999).

11. Dai F.C, Lee C.F, Ngai Y.YLandslide risk assessment and management overview. Engineering Geology 64, 65-87.(2002).
12. Agnesi V, Conoscenti C, Di Maggio C, Iudicello C, Rotigliano E Landslide hazard analysis in the Giardo River Basin (Middle-Western Sicily). Proceedings of the Workshop on Geomorphological sensitivity and system response. Università di Camerino - Università di Modena, Camerino, Italy, pp. 3-11(2003).

13. Agnesi V, Di Maggio C, Fiorito S, Rotigliano E Analytical approach for landslide hazard assessment in El Salvador (C.A). Proceedings of the symposium on Geomorphology: from expert opinion to modelling. CERG Editions, Strasbourg, France (2002).

14. Thiery $\mathrm{Y}$. Landslide susceptibility in the Barcelonnette basin (French South Alps): morphodynamic cartography, spatial analysis and probabilistic modelling. $\mathrm{PhD}$ Thesis, Caen/basseNormandieuniversity, Frensh. 445p (2007).

15. Thiery Y, Malet J-P, Sterlacchini S, Puissant A, Maquaire O. Landslide susceptibility assessment by bivariate methods at large scales: Application to a complex mountainous environment. Geomorphology 92 p38-59 (2007).

16. Carrara A, Cardinali M, Guzzetti F and Reichenbach P. GIS-based techniques for mapping landslide hazard. In "Geographical Information System in assessing natural hazard" A. Carrara \& F. Guzzetti (èds), KlinverAcadPubl., Dodrecht, pp. 135176 (1995).

17. El Gharbaoui A., La terre et l'Homme dans la péninsule tingitane. Etude sur l'Homme et le milieu dans le Rif occidental. Travaux de l'Institut Scientifique, série Géologie et Géographie Physique, Rabat, $\mathrm{n}^{\circ} 15,439 \mathrm{p}$ (1981).

18. Didon J., Durand Delga M. Et Kornprobst J. Homologies géologiques entre les deux rives du détroit de Gibraltar (Cordillères bétiques occidentales, Espagne). Bull. Soc.Géol.Fr., (7) XV, 2, p.77-105 (1973).

19. Durand-Delga M. et Mattauer G. sur l'origine ultrarifaine de certaines nappes du Rif septentrional. Comptes Rendus de la .Société Géologique Française, $n^{\circ} 2$, p. 22-23(1960).

20. Varnes D.J. Slope Movement Types and Processes. In Special Report 176: Landslides: Analysis and Control. In: Schuster, R.L., Krizek, R.J., (Eds), Transport Research Board, National Research, p1133 (1978).

21. Sawatzky, D. L., Raines, G. L., Bonham-Carter, G. F., Spatial Data Modeller (SDM) for ArcMAP 9.3 geoprocessing tools for spatial data modelling using weights of evidence, logistic regression, fuzzy logic and neural networks (2009).

22. Bonham-Carter G.F. Geographic Information Systems for Geoscientists: Modeling with GIS. Pergamon Press, Canada (1994).

23. Agterberg, F.P., and Cheng, Q., Conditional independence test for weights-of-evidence modeling: Natural Resources Research, v. 11, no. 4, p. 249-255 (2002), 